\title{
Role of dietary energy supplementation in growth of children with chronic renal insufficiency
}

\author{
P R BETTS, G MAGRATH, R H R WHITE
}

British Medical fournal, 1977, 1, 416-418

\section{Summary}

The effect of dietary energy supplements in children with varying degrees of chronic renal insufficiency was investigated. Despite an increased energy intake of $8.4 \%$ there was no increase growth velocity, although some patients reported improved wellbeing and activity. The proportion of dietary energy supplied by protein fell significantly during supplementation. The evidence suggests that the reduced energy intake of children with chronic renal insufficiency is a related but not causal factor in their growth retardation.

\section{Introduction}

Short stature in children with chronic renal insufficiency was first described in $1897 .{ }^{1}$ Although there are several contributory factors. ${ }^{2-4}$ a reduced energy intake is thought to be one of the most important causes of this growth retardation. We have previously reported reduced growth velocity in children with impaired renal function and energy intakes below $80^{\circ}{ }_{0}$ of that recommended for age. ${ }^{2}$ It is unclear, however, whether this reduced energy intake is the cause or result of the reduced growth velocity, nor is it known whether significant catch-up growth occurs when energy intake is increased.

Simmons $\mathrm{et} \mathrm{al}^{4}$ reported increased growth velocity after dietary energy supplementation in children receiving intermittent haemodialysis. They studied only a few children, however, and

\footnotetext{
Department of Nephrology, Children's Hospital, Birmingham, B16 8ET

P R BETTS, MB, MRCP, renal research fellow (now lecturer in paediatrics and child health, University of Birmingham)

G MAGRATH, SRD, senior dietician

R H R WHITE, MD, FRCP, consultant paediatrician and nephrologist
}

in some growth increments were measured over only three months. Similar short-term increments in growth velocity have been shown in uraemic rats given extra energy in the form of corn oil. ${ }^{3}$ To draw firm conclusions on the long-term benefits and effectiveness of energy supplementation on growth, longitudinal data over at least 12 months are required. ${ }^{6}$

We report here observations on the growth of children with varying degrees of chronic renal insufficiency who were given energy supplements over 12 months.

\section{Patients and methods}

The 17 children (13 boys) studied were attending the renal clinic at Birmingham Children's Hospital. Their ages ranged from 0.6 to 13.9 years. All had glomerular filtration rates (GFR) persistently below $70 \mathrm{ml} / \mathrm{min} / 1.73 \mathrm{~m}^{2}$ as assessed by endogenous creatinine clearance ${ }^{\bar{j}}$ or, in those with reflux nephropathy, the slope clearance of ${ }^{51} \mathrm{Cr}$-labelled edetic acid. ${ }^{8}$

Changes in renal function during the study were assessed by determining blood urea concentrations every three months and GFR every six months. The mean values are reported.

Apart from a 6-month-old infant, all children had been observed for at least a year before this investigation, so that their growth velocity could be determined both before and during energy supplementation. An increase in growth velocity greater than $1.5 \mathrm{~cm} /$ year was considered significant, since higher rates are seldom observed before puberty. Height was measured with a wall stadiometer and centiles were plotted using the charts of Tanner et al. ${ }^{10}$ Bone age was assessed by the method of Greulich and Pyle. ${ }^{11}$ Puberty was scored according to the method of Tanner. ${ }^{12}$

The children were divided into two groups on the basis of their initial energy intakes. Group 1 (six children) had a dietary energy intake greater than $80 \%$ of the recommended dietary allowance for age $^{13}$ and received no energy supplementation. Group 2 (11 children) consisted of six children with dietary energy intakes less than $80 \%$ and five children with intakes greater than $80 \%$ of the recommended dietary allowance. All received dietary energy supplements in the form of Caloreen which was given in drinks or sprinkled on food at intervals throughout the day. Caloreen (Scientific Hospital Supplies Limited, Liverpool) is a glucose polymer with an average length of five glucose units. It is relatively non-sweet and, because it has an osmotic pressure one-fifth that of glucose, causes little or no gastrointestinal irritation.

TABLE I-Clinical data before energy supplementation

\begin{tabular}{|c|c|c|c|c|c|c|c|c|}
\hline $\begin{array}{l}\text { Case } \\
\text { - No }\end{array}$ & Sex & $\underset{\text { (years) }}{\text { Age }}$ & $\begin{array}{c}\text { Bone } \\
\text { age } \\
\text { (years) }\end{array}$ & $\begin{array}{c}\mathrm{GFR} \\
(\mathrm{ml} / \mathrm{min} / \\
\left.1.73 \mathrm{~m}^{2}\right)\end{array}$ & $\begin{array}{c}\begin{array}{c}\text { Blood } \\
\text { urea } \\
(\mathrm{mmol} / \mathrm{l})\end{array} \\
\end{array}$ & $\underset{(\mathrm{cm})}{\text { Height }}$ & $\begin{array}{c}\text { Growth } \\
\text { velocity } \\
\text { (cm/year) }\end{array}$ & Diagnosis \\
\hline \multicolumn{9}{|c|}{ Group 1} \\
\hline $\begin{array}{l}1 \\
2 \\
3 \\
4 \\
5 \\
6\end{array}$ & $\begin{array}{l}M \\
M \\
M \\
M \\
F \\
M\end{array}$ & $\begin{array}{l}4 \cdot 0 \\
4 \cdot 5 \\
4 \cdot 6 \\
5 \cdot 3 \\
8 \cdot 1 \\
9 \cdot 3\end{array}$ & $\begin{array}{l}3 \cdot 0 \\
3 \cdot 5 \\
3 \cdot 5 \\
2 \cdot 5 \\
6 \cdot 0 \\
7 \cdot 5\end{array}$ & $\begin{array}{l}58 \\
44 \\
68 \\
24 \\
32 \\
21\end{array}$ & $\begin{array}{r}5 \cdot 3 \\
5 \cdot 7 \\
5 \cdot 5 \\
13 \cdot 2 \\
15 \cdot 2 \\
11 \cdot 3\end{array}$ & $\begin{array}{c}98 \\
93 \cdot 8 \\
99 \cdot 5 \\
100 \\
123 \cdot 8 \\
129\end{array}$ & $\begin{array}{l}7 \cdot 8 \\
3 \cdot 8 \\
6 \cdot 0 \\
5 \cdot 6 \\
5 \cdot 5 \\
4 \cdot 3\end{array}$ & $\begin{array}{l}\text { Reflux nephropathy } \\
\text { Urethral valve } \\
\text { Interstitial nephritis } \\
\text { Unclassified } \\
\text { Juvenile nephronophthisis } \\
\text { Reflux nephropathy }\end{array}$ \\
\hline \multicolumn{9}{|c|}{ Group 2} \\
\hline $\begin{array}{r}7 \\
8 \\
9 \\
10 \\
11 \\
12 \\
13 \\
14 \\
15 \\
16 \\
17\end{array}$ & $\begin{array}{l}\mathrm{M} \\
\mathrm{F} \\
\mathrm{M} \\
\mathrm{M} \\
\mathrm{F} \\
\mathrm{M} \\
\mathrm{F} \\
\mathrm{M} \\
\mathrm{M} \\
\mathrm{M} \\
\mathrm{M}\end{array}$ & $\begin{array}{r}0 \cdot 6 \\
2 \cdot 8 \\
4 \cdot 5 \\
4 \cdot 9 \\
5 \cdot 9 \\
6 \cdot 9 \\
8 \cdot 3 \\
9 \cdot 5 \\
11 \cdot 3 \\
13 \cdot 5 \\
13 \cdot 9\end{array}$ & $\begin{array}{l}0 \cdot 75 \\
1 \cdot 0 \\
4 \cdot 5 \\
2 \cdot 3 \\
7 \cdot 0 \\
4 \cdot 5 \\
8 \cdot 0 \\
8 \cdot 0 \\
8 \cdot 0 \\
12 \cdot 0 \\
12 \cdot 0\end{array}$ & $\begin{array}{r}5 \\
20 \\
68 \\
46 \\
47 \\
40 \\
61 \\
17 \\
9 \\
12 \\
10\end{array}$ & $\begin{array}{r}11 \cdot 2 \\
14 \cdot 7 \\
6 \cdot 0 \\
6 \cdot 0 \\
8 \cdot 3 \\
8 \cdot 7 \\
8 \cdot 0 \\
27 \cdot 2 \\
36 \cdot 0 \\
23 \cdot 0 \\
25 \cdot 0\end{array}$ & $\begin{array}{r}62 \cdot 1 \\
78 \cdot 5 \\
107 \cdot 1 \\
101 \cdot 2 \\
120 \cdot 1 \\
116 \\
124 \cdot 2 \\
128 \cdot 6 \\
119 \cdot 5 \\
153 \cdot 7 \\
136 \cdot 7\end{array}$ & $\begin{array}{l}4 \cdot 1 \\
6 \cdot 5 \\
6 \cdot 1 \\
5 \cdot 5 \\
5 \cdot 1 \\
6 \cdot 2 \\
4 \cdot 1 \\
2 \cdot 6 \\
5 \cdot 7 \\
2 \cdot 8\end{array}$ & $\begin{array}{l}\text { Dysplasia } \\
\text { Dysplasia } \\
\text { Haemolytic uraemic syndrome } \\
\text { Reflux nephropathy } \\
\text { Haemolytic uraemic syndrome } \\
\text { Reflux nephropathy } \\
\text { Reflux nephropathy } \\
\text { Reflux nephropathy } \\
\text { Dysplasia } \\
\text { Dysplasia } \\
\text { Reflux nephropathy }\end{array}$ \\
\hline
\end{tabular}


TABLE II-Energy and protein intakes before and during energy supplementation

\begin{tabular}{|c|c|c|c|c|c|c|c|c|c|}
\hline \multirow{2}{*}{$\begin{array}{l}\text { Case } \\
\text { No }\end{array}$} & \multicolumn{4}{|c|}{ Before supplementation } & \multicolumn{5}{|c|}{ During supplementation } \\
\hline & $\begin{array}{c}\text { Total energy } \\
\text { intake } \\
(\mathrm{MJ} / \text { day })\end{array}$ & $\begin{array}{c}\text { Energy } \\
\text { intake } \\
\left({ }_{0}^{0} \text { RDA }\right)\end{array}$ & $\begin{array}{c}\text { Protein } \\
\text { intake } \\
\text { (g/day) }\end{array}$ & $\begin{array}{l}\text { Energy } \\
\text { as protein }\end{array}$ & $\begin{array}{c}\text { Total energy } \\
\text { intake } \\
(\mathrm{MJ} / \text { day })\end{array}$ & $\begin{array}{c}\text { Energy } \\
\text { intake } \\
(\% \text { RDA })\end{array}$ & $\begin{array}{c}\text { Energy } \\
\text { supplement } \\
(\mathrm{MJ} / \text { day })\end{array}$ & $\begin{array}{c}\text { Protein } \\
\text { intake } \\
\text { (g/day) }\end{array}$ & $\begin{array}{l}\% \text { Energy } \\
\text { as protein }\end{array}$ \\
\hline \multicolumn{10}{|c|}{ Group 1} \\
\hline $\begin{array}{l}1 \\
2 \\
3 \\
4 \\
5 \\
6\end{array}$ & $\begin{array}{r}5.60 \\
6.93 \\
5.61 \\
7.44 \\
8.57 \\
10.62\end{array}$ & $\begin{array}{r}82 \\
102 \\
81 \\
103 \\
97 \\
110\end{array}$ & $\begin{array}{l}38 \\
33 \\
45 \\
48 \\
53 \\
45\end{array}$ & $\begin{array}{r}12 \\
8 \\
13 \\
11 \\
10 \\
7\end{array}$ & $\begin{array}{r}6 \cdot 31 \\
5 \cdot 27 \\
6 \cdot 10 \\
8 \cdot 67 \\
10.58 \\
11 \cdot 36\end{array}$ & $\begin{array}{r}91 \\
89 \\
86 \\
98 \\
117 \\
108\end{array}$ & & $\begin{array}{l}33 \\
36 \\
44 \\
51 \\
70 \\
74\end{array}$ & $\begin{array}{l}9 \\
11 \\
12 \\
10 \\
11 \\
11\end{array}$ \\
\hline \multicolumn{10}{|c|}{ Group 2} \\
\hline $\begin{array}{r}7 \\
8 \\
9 \\
10 \\
11 \\
12 \\
13 \\
14 \\
15 \\
16 \\
17\end{array}$ & $\begin{array}{r}2.88 \\
3.94 \\
5.86 \\
6.65 \\
4.68 \\
5.60 \\
8.47 \\
7.28 \\
7.03 \\
11.33 \\
6.73\end{array}$ & $\begin{array}{l}87 \\
66 \\
85 \\
93 \\
62 \\
68 \\
96 \\
75 \\
65 \\
97 \\
57\end{array}$ & $\begin{array}{l}15 \\
28 \\
40 \\
45 \\
29 \\
37 \\
76 \\
55 \\
48 \\
60 \\
40\end{array}$ & $\begin{array}{r}9 \\
12 \\
11 \\
11 \\
10 \\
11 \\
15 \\
13 \\
11 \\
9 \\
10\end{array}$ & $\begin{array}{r}3 \cdot 67 \\
5 \cdot 92 \\
6 \cdot 70 \\
8 \cdot 13 \\
7 \cdot 10 \\
6 \cdot 28 \\
9 \cdot 02 \\
7 \cdot 70 \\
8 \cdot 93 \\
10 \cdot 46 \\
8 \cdot 36\end{array}$ & $\begin{array}{r}85 \\
90 \\
91 \\
109 \\
87 \\
71 \\
97 \\
74 \\
80 \\
90 \\
69\end{array}$ & $\begin{array}{l}0.50 \\
2.14 \\
2.09 \\
2.06 \\
1.32 \\
1.72 \\
0.75 \\
1.14 \\
1.84 \\
1.67 \\
1.93\end{array}$ & $\begin{array}{l}17 \\
30 \\
25 \\
41 \\
34 \\
29 \\
64 \\
46 \\
55 \\
58 \\
41\end{array}$ & $\begin{array}{r}8 \\
8 \\
6 \\
8 \\
8 \\
8 \\
12 \\
10 \\
10 \\
9 \\
8\end{array}$ \\
\hline
\end{tabular}

RDA = Recommended dietary allowance.

Conversion: SI to traditional units-Energy: $1 \mathrm{MJ} \approx 240 \mathrm{kcal}$

A three-day dietary intake was weighed ${ }^{2}$ by the mothers of these children at the start of the study, at six weeks, and then every three months for 12 months. The child and mother were seen every three months, and when appropriate the energy supplementation was increased so long as the mother thought that the child would accept it. Particular care was taken to ensure that the full amount of Caloreen was being ingested and that the weighed recordings were accurate assessments of dietary intake. The mean energy and protein intake during the study were then compared with the recommended dietary allowances for British children of similar age. ${ }^{13}$

\section{Results}

The clinical, renal, and anthropometric data of the 17 children studied are given in table I. Only two children showed pubertal development (case 16: pubic hair stage IV, genital stage III ; and case 17: pubic hair stage II, genital stage II). At the start of the study there were no significant differences between the ages, blood urea concentrations, or GFR of the children in group 1 or 2 , although children in group 2 tended to be older and have poorer renal function.

Energy intake-Although five of the six children in group 1 spontaneously increased their total energy intakes over the 12-month study period, when these were expressed as a percentage of those recommended for their age no significant increase in energy intake had occurred $(t=1.22 ; \mathrm{P}=>0 \cdot 2$, using the paired Student's $t$ test) (table II). The 11 children in group 2 received a mean energy supplement of $1.56 \mathrm{MJ} /$ day (375 kcal/day) (range 0.50-2.14 MJ (120$512 \mathrm{kcal}$ )) in the form of Caloreen (table II). This constituted, on average, $21 \%$ of the total energy that they ingested (range $8 \%-36 \%$ ). Ten of the 11 children increased their total energy intake during the period of study, and when this was expressed as a percentage of that recommended for age the group had significantly increased their intake by a mean of $8.4 \%(t=2.58 ; \mathrm{P}=>0.05)$. The five children with initial intakes greater than $80 \%$ of the recommended dietary allowance, however, showed only a 3\% increase. The six children with energy intakes below $80 \%$ increased theirs by $13 \%$, three of them thereby exceeding $80 \%$ of the recommended intake.

Protein intake-Before the study all the children had protein intakes constituting about $11 \%$ of their daily energy intake (table II). In group 1 there was no significant increase in protein intake in relation to age during the study. Of the 11 children taking Caloreen, however, six actually reduced their protein intake. The proportion of energy supplied by protein in their diet also fell significantly from a mean of $11 \cdot 1 \%$ to $8 \cdot 6 \%(t=5 \cdot 65 ; \mathrm{P}=>0.001)$.

Growth velocity-The changes in growth velocity during the study in groups 1 and 2 are shown in tables I and III. Chronological age was used for calculating height velocity in all the children, including the two boys aged 13.5 and 13.9 years with early pubertal changes and slightly reduced bone age.

Only three children showed growth acceleration greater than 1.5 $\mathrm{cm} /$ year (cases 2,8 , and 16) irrespective of their GFR and whether or not they were given energy supplements. One patient (case 2 ) received
TABLE III-Renal and growth data during energy supplementation

\begin{tabular}{|c|c|c|c|}
\hline $\begin{array}{l}\text { Case } \\
\text { No }\end{array}$ & $\begin{array}{c}\text { Mean } \\
\text { blood urea } \\
(\mathrm{mmol} / \mathrm{l})\end{array}$ & $\begin{array}{c}\text { Mean } \\
\text { GFR } \\
\left(\mathrm{ml} / \mathrm{min} / 1 \cdot 73 \mathrm{~m}^{2}\right)\end{array}$ & $\begin{array}{c}\text { Growth } \\
\text { velocity } \\
\text { (cm/year) }\end{array}$ \\
\hline \multicolumn{4}{|c|}{ Group 1} \\
\hline $\begin{array}{l}1 \\
2 \\
3 \\
4 \\
5 \\
6\end{array}$ & $\begin{array}{r}4.3 \\
8.5 \\
5.7 \\
14.0 \\
17.5 \\
18.3\end{array}$ & $\begin{array}{l}58 \\
46 \\
76 \\
23 \\
40 \\
17\end{array}$ & $\begin{array}{l}6.5 \\
5.9 \\
5.5 \\
5.8 \\
6.5 \\
4.5\end{array}$ \\
\hline \multicolumn{4}{|c|}{ Group 2} \\
\hline $\begin{array}{r}7 \\
8 \\
9 \\
10 \\
11 \\
12 \\
13 \\
14 \\
15 \\
16 \\
17\end{array}$ & $\begin{array}{r}18 \cdot 2 \\
14.3 \\
6.3 \\
10 \cdot 0 \\
10 \cdot 5 \\
10 \cdot 7 \\
10 \cdot 2 \\
40 \cdot 3 \\
45 \cdot 5 \\
30 \cdot 0 \\
26.5\end{array}$ & $\begin{array}{r}15 \\
16 \\
69 \\
46 \\
62 \\
30 \\
61 \\
9 \\
8 \\
9 \\
7\end{array}$ & $\begin{array}{r}11.7 \\
6.3 \\
5.2 \\
5.8 \\
5.1 \\
5.0 \\
6.7 \\
5.2 \\
4.0 \\
7.8 \\
3.9\end{array}$ \\
\hline
\end{tabular}

no supplements and, from the dietary information obtained, actually reduced his caloric intake over this period. The increased velocity in case 16 might have been explained by his pubertal growth spurt. Only case 8 showed significant growth acceleration that could not be explained other than by caloric supplementation.

Renal function-During the year's study there was little change in the renal function of the children in group 1 (tables I and III). In group 2, however, six of the 11 children showed a reduction in GFR, although the mean throughout the year remained at $32 \mathrm{ml} / \mathrm{min} / 1.73$ $\mathrm{m}^{2}$. In addition, the mean blood urea concentration in group 2 increased to $20 \cdot 1 \mathrm{mmol} / 1(121 \mathrm{mg} / 100 \mathrm{ml})$, and five of the 11 children had an increase greater than $4 \mathrm{mmol} / \mathrm{l}(24 \mathrm{mg} / 100 \mathrm{ml})$ over this period. This increase in the blood urea concentration occurred despite an increased energy intake and proportionate decrease in the percentage of energy supplied by protein.

\section{Discussion}

We have previously reported that growth velocity may be reduced in children with chronic renal insufficiency and energy intakes below $80 \%$ of that recommended for age. ${ }^{2}$ Our findings have shown that despite an increase in energy intake of $8.4 \%$ through energy supplementation in children with renal insufficiency there was no significant increase in their growth velocity. Only two children in group 2 increased their growth velocity by more than $1.5 \mathrm{~cm} /$ year, and in one of these puberty may have been responsible. One child in group 1, not receiving energy supplements, also increased his growth velocity by the 
same amount. These data suggest that the decreased energy intake of children with chronic renal insufficiency is a related but not causal factor in their reduced growth velocity.

Attempts to increase the energy intake over that recommended for age by dietary supplementation were defeated in those children with normal intakes. Despite Caloreen contributing a mean of $19 \%$ of their daily energy requirements their total energy intakes increased only $3^{\circ}{ }_{0}$-that is, they merely reduced their intake of other substances. We therefore cannot say whether successful supplementation would have led to catch-up growth or merely an increase in weight.

For the healthy child the caloric cost of growth is probably only $10 \%$ of the total energy intake, the remainder being divided between the metabolic rate and physical activity. Ashworth, ${ }^{14}$ studying malnourished children with a prolonged reduction in energy intake, showed only a slight reduction in basal metabolic rate, while physical activity and growth were compromised to a greater extent. This may also have occurred in the children we studied, but physical activity is difficult to assess. Several mothers stated, however, that their children's wellbeing and activity improved while they were receiving energy supplements. Energy supplements may therefore be of some benefit in children with moderate to severe degrees of renal insufficiency.

Normally $10-15^{\circ}$ of the total energy intake of British children consists of protein ${ }^{13}$; the mean percentage in our patients was $11^{\circ}$. Six of the 11 children receiving supplements reduced their protein intake over the ensuing year, and in all 11 children there was a decrease in the percentage of energy obtained from protein. This observed reduction in protein intake may be related to the absence of observed growth acceleration or may be merely a reflection of appetite depression due to an extra carbohydrate intake. Since extra energy from Caloreen was not used for catchup growth, however, dietary nitrogen intake may have been selectively reduced to limit its excretion by malfunctioning kidneys.
When renal disease dates from infancy-a time of maximal growth velocity-impaired function may result in reduced growth and permanent stunting." Since this may well result from a reduced energy intake, supplementation must be started in the first few months of life if it is to prevent growth retardation. As we have already emphasised, ${ }^{15}$ it is important that chronic renal insufficiency should be diagnosed early and that management of children with this condition should be improved. Only then can the role of energy supplementation be properly assessed.

This work was supported by project grant No G972/143/C from the Medical Research Council.

\section{References}

${ }^{1}$ Guthrie, L G, Lancet, 1897, 2, 585.

${ }^{2}$ Betts, P R, and Magrath, G, British Medical fournal, 1974, 2, 189.

${ }^{3}$ Chantler, C, and Holliday, M A, Clinical Nephrology, 1973, 1, 230.

${ }^{4}$ Simmons, J M, et al, New England fournal of Medicine, 1971, 285, 653.

5 Chantler, C, et al, Paper read at Paediatric Research Society, October, 1973.

${ }^{6}$ Marshall, W A, Archives of Disease in Childhood, 1971, 46, 414.

7 Glasgow, E F, Moncreiff, M W, and White, R H R, British Medical fournal, $1970,2,687$.

${ }^{8}$ Chantler, C, and Barratt, T M, Archives of Disease in Childhood, 1972, 47, 613.

9 Tanner, J M, et al, Archives of Disease in Childhood, 1971, 46, 745.

10 Tanner, J M, Whitehouse, R M, and Takaishi, M, Archives of Disease in Childhood, 1966, 41, 454.

11 Greulich, W W, and Pyle, S I, Radiographic Atlas of Skeletal Development of Hand and Wrist, 2nd edn. California, Standford University Press, 1959.

12 Tanner, J M, Growth at Adolescence. Oxford, Blackwell Scientific, 1962.

${ }^{13}$ Department of Health and Social Security, Recommended Intakes of Nutrients for the United Kingdom. London, HMSO, 1969.

${ }_{14}$ Ashworth, A, British fournal of Nutrition, 1968, 22, 341.

15 Betts, P R, and White, R H R, Nephron, 1976, 16, 325.

(Accepted 15 December 1976)

\title{
Inhibition of gastric secretion in treatment of pancreatic insufficiency.
}

\author{
J H B SAUNDERS, S DRUMMOND, K G WORMSLEY
}

British Medical fournal, 1977, 1, 418-419

\section{Summary}

The content of pancreatic enzymes in the duodenum was studied in two patients with pancreatic achylia after a standard meal supplemented with commercial pancreatic extract. Gastric transit of the enzymes, with appearance of near-normal amounts in the duodenal contents, occurred only after inhibition of gastric secretion and buffering of residual gastric acid with antacids. Gastric inhibition and neutralisation of acid are therefore necessary for the satisfactory treatment of patients with pancreatic exocrine insufficiency but normal gastric function.

\footnotetext{
University Department of Therapeutics, Ninewells Hospital, Dundee DD2 1UB

J H B SAUNDERS, MB, MRCP, medical registrar

$S$ DRUMMOND, BSC, research assistant

K G WORMSLEY, DSC, FRCP, consultant physician
}

\section{Introduction}

The destruction of pancreatic enzymes by gastric acid and pepsin is the most important of the factors that vitiate the satisfactory treatment of pancreatic exocrine insufficiency with supplements of pancreatic extracts by mouth. ${ }^{1}$ We have therefore studied the effects on the gastric transit of enzymes in such an extract, given with a meal, of inhibiting gastric secretion with the $\mathrm{H}_{2}$-receptor-blocking drug metiamide.

\section{Materials and methods}

Two patients with chronic pancreatitis and pancreatic achylia, confirmed by lack of pancreatic response to stimulation with secretin and cholecystokinin, ${ }^{2}$ gave informed consent to each study. After an overnight fast a multilumen tube was sited with its tip in the distal duodenum. A liquid meal containing protein $16.7 \mathrm{~g} / \mathrm{l}$ (Casilan) and starch $56.7 \mathrm{~g} / \mathrm{l}$ was given by mouth. Gastric and duodenal contents were sampled at intervals of 10 minutes. After 50 minutes each patient received a further, identical meal containing the contents of three capsules of pancreatic extract with previously determined high content of potent pancreatic enzymes. ${ }^{3}$

Each patient then began treatment with a total of $1 \mathrm{~g}$ metiamide daily. On the day of the test the last dose was given 90 minutes before 